\title{
Upaya Pimpinan Dalam Meningkatkan Etos Kerja Asatidz Pengabdian di Pondok Pesantren Ibnul Qoyyim Putra Yogyakarta
}

\author{
AM Saifullah Aldeia \\ Balai Litbang Agama Makassar \\ Amshawell@gmail.com
}

\begin{tabular}{l}
\hline Article Info \\
\hline Article history: \\
Received 28 Desember 2021 \\
Accepted 8 Januari 2022 \\
Published 8 Januari 2022 \\
Page : 68 - 84 \\
\hline
\end{tabular}

Keyword:

Etos Kerja,

Kepemimpinan, Pesantren

\begin{abstract}
Today, the discussion about work ethic is becoming increasingly important. Moreover, the work ethic of caregivers in pesantren. The formulation of the problem from this research is how is the work ethic of asatidz devotion at the Ibnul Qoyyim Putra Islamic boarding school; What are the factors that influence the work ethic of asatidz Islamic boarding school service Ibnul Qoyyim Putra; What is the role of leadership in improving the work ethic of asatidz in the service of the Ibnul Qoyyim Putra Islamic boarding school. This research is a qualitative research. This study uses a phenomenological approach. The subjects of this study were the director and deputy director and Asatidz for the service of the Ibnul Qoyyim Putra Islamic boarding school. Data was collected using the methods of observation, interviews, and documentation. The results of this study indicate that: (1) The work ethic of asatidz devotion at the Ibnul Qoyyim Putra Islamic boarding school is quite good. The indicators are polite loyalty, humble, patient, and have stable emotions. (2) the factors that influence the work ethic of asatidz devotion, namely intrinsic and extrinsic motivation (3) The role of leadership in improving work ethic is to give appreciation to asatidz who have good performance, evaluate asatidz whose performance is not good, become a motivator for asatidz devotion and create a family atmosphere between leaders and service asatidz.
\end{abstract}

Dewasa ini, pembahasan tentang etos kerja menjadi semakin penting. Terlebih etos kerja pengasuh di pesantren. Rumusan masalah dari penelitian ini adalah bagaimana Bagaimana etos kerja asatidz pengabdian di pondok pesantren Ibnul Qoyyim Putra; Apa faktor-faktor yang mempengaruhi etos kerja asatidz pengabdian pondok pesantren Ibnul Qoyyim Putra; Bagaimana peran pimpinan dalam meningkatkan etos kerja asatidz pengabdian pondok pesantren Ibnul Qoyyim Putra. Penelitian ini adalah penelitian kualitatif. Penelitian ini menggunakan pendekatan Fenomenologi. Subjek dari penelitian ini adalah direktur dan wakil direktur pondok pesantren Ibnul Qoyyim Putra dan Asatidz pengabdian pondok pesantren Ibnul Qoyyim Putra. Hasil penelitian ini menunjukkan bahwa : (1) Etos kerja asatidz pengabdian di pondok pesantren Ibnul Qoyyim Putra sudah cukup baik. Indikator baiknya etos kerja dapat dilihat dari loyalitas atau kesetiaan para asatidz untuk melaksanakan pengabdian. (2) faktor yang mempengaruhi etos kerja asatidz pengabdian yaitu motivasi baik intrinsik maupun ekstrinsik, faktor yang dalam hal ini adalah honor yang diberikan pihak pesantren, motivasi dari pimpinan pesantren, etos kerja rekan pengabdian yang lain, dan pengaruh keilmuan Islam yang berkaitan dengan etos kerja. (3) Peran pimpinan dalam meningkatkan etos kerja yaitu memberikan apresiasi kepada asatidz pengabdian yang kinerjanya baik, melakukan evaluasi terhadap asatidz yang kinerjanya kurang baik, menjaadi motivator untuk asatidz pengabdian dan menciptakan suasana kekeluargaan antara pimpinan dengan asatidz pengabdian.

Copyright (C) 2022 Journal Of Islamic Management. All rights reserved.

Editorial Office:

Program Studi Manajemen Dakwah, Fakultas Dakwah dan Komunikasi, UIN Sunan Ampel Surabaya.

Jl. Ahmad Yani 117 Surabaya, Jawa Timur, Indonesia.

Email: jim@uinsby.ac.id 


\section{Pendahuluan}

Pondok pesantren merupakan lembaga pendidikan yang mendidik peserta didiknya (santri) agar dapat memahami keilmuan agama dengan baik. Tidak cukup disitu, pondok pesantren juga membiasakan santrinya untuk berakhlak terpuji agar dapat menjadi teladan yang baik di lingkungan sosial tempatnya berinteraksi. Ciri khas tersebut yang membuat pondok pesantren dikenal oleh masyarakat sebagai lembaga pendidikan Islam yang memiliki peranan penting untuk mencerdaskan bangsa baik dari segi kognitif, perilaku maupun spiritual. Seiring perkembangan zaman pondok pesantren terus berbenah diri agar bisa mendidik para santrinya untuk menjadi pribadi yang tidak hanya memahami keilmuan agama dengan baik dan mendalam namun juga bisa mengembangkan teknologi terkini yang bermanfaat untuk masyarakat.

Saat ini banyak dijumpai pesantrenpesantren yang berkembang di Indonesia. Setiap pesantren mempunyai ciri khas yang berbeda. Namun secara garis besar pesantren-pesantren yang ada di Indonesia dikatagorikan ke dalam 3 bentuk yaitu : (a) Pondok pesantren salafiyah; (b) Pondok pesantren Khalafiyah; Pondok Psaantren campuran/kombinasi ${ }^{1}$. Pondok pesantren Salafiyah adalah pondok pesantren yang sistem pembelajarannya menggunakan pendekatan tradisional dan berkonsentrasi pada pembahasan kitab kuning berbahasa arab. Sedangkan pondok pesantren Khalafiyah (modern) merupakan pondok pesantren yang menyelenggarakan kegiatan pendidikan dengan pendekatan modern melalui satuan pendidikan formal, baik madrasah ( MI, MTs, MA, atau MAK), maupun sekolah (SD, SMP, SMA, SMK). Pada pondok pesantren Khalafiyah, "pondok" lebih banyak berfungsi sebagai

\footnotetext{
1 Muhammad Nihwan dan Paisun, "Tipologi Pesantren (Mengkaji Sistem Salaf dan Modern)," Jpik 2, no. 1 (2019).
}

asrama yang memberikan lingkungan kondusif untuk pendidikan agama. Adapun pondok pesantren kombinasi merupakan penggabungan dua sistem antara salafiyah dengan khalafiyah. Artinya pessantren tersbut mengadakan pendidikan formal berjenjang namun juga menerapkan sistem pendidikan tradisional yang berkonsentrasi pada pembahasan kitab kuning ${ }^{2}$.

Dari tiga kategori pesantren yang telah disebutkan semuanya mempunyai ciri khas masing-masing. namun ada satu hal yang menjadi persamaan dari tiga kategori pesantren tersebut, yaitu proses pendidikannya berlangsung selama 24 jam penuh dan berkesinambungan. Menjadi ciri khas sebuah pessantren adalah para peserta didiknya (santri) bermukim di asrama yang sudah disediakan pihak pesantren.

Dengan demikian segala hal yang dilihat, didengar, dan dikerjakan walaupun dalam beberapa kasus ada santri yang hanya datang ke pesantren sore hari untuk belajar kitab (santri kalong), idealnya para santri haruslah bermukim di asrama agar pendidikan pesantrennya bisa tertanam kuat.

Pola pendidikan pesantren yang berlangsung selama 24 jam ini menuntut para pengelola maupun pengasuh untuk bekerja maksimal agar tujuan-tujuan pendidikan yang dicanangkan oleh pesantren bisa dicapai oleh para santri. Untuk itu pengelolaan pesantren membutuhkan sumber daya manusia berkualitas dan memahami pola pendidikan pesantren dengan baik.

Sumber daya manusia dalam hal ini adalah pengasuh. Namun kualitas dan kemampuan mengelola pendidikan pesantren tidaklah cukup jika tidak dibarengi dengan etos kerja yang baik dari pengasuh yang ada. Dengan adanya etos

\footnotetext{
${ }^{2}$ Salman Al Farisi, "MODEL INTEGRASI STUDI ISLAM: SAINS DAN BUDAYA NUSANTARA DI PESANTREN KHOLAF," Jurnal Penelitian Agama 19, no. 1 (2018).
} 
kerja yang baik maka seseorang akan bekerja keras dengan dedikasi tinggi dan kejujuran. Etos kerja yang baik juga mendorong seseorang untuk memiliki pandangan dan sikap yang menghargai kerja sebagai sesuatu yang luhur untuk eksitensi manusia. Dewasa ini, pembahasan tentang etos kerja menjadi semakin penting. Hal ini dikarenakan dilema kerja semakin kompleks ${ }^{3}$. Terlebih etos kerja pengasuh di pesantren. Karena input maupun output dari pesantren adalah manusia yang harus dikembangkan potensi-potensinya.

Etos kerja merupakan refleksi dari sikap hidup yang mendasar, maka etos kerja pada dasarnya juga merupakan cerminan dari pandangan hidup yang berorientasi pada nilai yang berdimensi pada transenden. Nilai-nilai transeden itu akan menjadi dasar bagi pengembangan spiritualitas yang sangat diperlukan sebagai kekuatan yang membentuk suatu kepribadian yang menentukan kualitas eksistensial dalam hidupnya ${ }^{4}$. Janan Asifudin mengemukakan adanya kemungkinan etos kerja manusia terwujud sebagai hasil dari suatu proses sosial historis. Berarti etos kerja bukan suatu sifat yang konstan . ia bisa mengalami pasang surut. Janan Asifudin juga berpendapat bahwa etos kerja adalah suatu kebudayaan. Terbentuk oleh proses yang panjang dan pada akhirnya membentuk sebuah kepribadian. Dengan demikian dapat ditemui perbedaan etos kerja antara satu kelompok dengan kelompok lainnya. Dapat disimpulkan bahwa etos kerja merupakan bagian dari budaya, upaya pembinaan dan peningkatan etos kerja individu ataupun kelompok ${ }^{5}$.

3 Tarmizi Gadeng, "Etos Kerja Dalam Perspektif Islam (Peluang Dan Tantangan Profesionalisme Masyarakat Muslim Dalam Era Modern)," Jurnal Mentari: Majalah Ilmiah Universitas Muhammadiyah Aceh 12, no. 1 (2009).

4 Musa Asy'arie, "Islam Etos Kerja dan Pemberdayaan Ekonomi Umat," in Islam Etos Kerja dan Pemberdayaan Ekonomi Umat, 1997.
Seperti yang telah dipaparkan di atas, bahwasanya etos kerja bukanlah suatu hal yang konstan melainkan mengalami peningkatan maupun penurunan. Menurunnya etos kerja seseorang akan berdampak pada kualitas kerjanya. Jika dilihat dari sisi organisasi maupun kelembagaan, penurunan etos kerja dapat memperlambat perkembangan lembaga tersebut. lembaga tersebut. Menurunnya etos kerja seseorang bisa disebabkan oleh faktor internal maupun faktor eksternal.

Faktor internal adalah pengaruh yang datang dari dalam seseorang seperti kejenuhan dalam melaksanakan sebuah tugas sehingga menurunkan etos kerjanya. Sedangkan faktor eksternal adalah halhal yang datang dari luar seperti rekan kerja yang kurang baik, sistem yang tidak berjalan dengan baik maupun metode kepemimpinan yang kurang baik ${ }^{6}$. Menurunnya etos kerja dapat menghambat perkembangan sebuah lembaga pendidikan tidak terkecuali pondok pesantren.

Salah satu faktor yang menyebabkan turunnya etos kerja asatidz pengabdian adalah kejenuhan dalam melaksnakan tugas-tuga pesantren. Indikasi kejenuhan dapat dilihat dari berjalannya kegiatan-kegiatan pesantren yang kurang maksimal kegiatan-kegiatan tersebut diantaranya adalah kumpul rutin mingguan antara asatidz dengan para santri kamar yang dibimbing. Beberapa asatidz tidak menghadiri forum tersebut sehingga keadaan santri kurang kondusif dan menjadi tidak disiplin. Beberapa asatidz juga tidak melaksanakan bimbingan belajar kepada para santri yang sudah ditetapkan jadwalnya. Dalam

\footnotetext{
5 Muhammad Irham, "Work Ethics in Islamic Perspective," Jurnal Substantia 14, no. 1 (2012).

6 Diyah Fitriyani, Ocky Sundari, dan Johnson Dongoran, "FAKTOR-FAKTOR YANG MEMPENGARUHI ETOS KERJA PEGAWAI KECAMATAN SIDOREJO SALATIGA," Jurnal Ilmu Sosial dan Humaniora 8, no. 1 (2019).
} 
koordinasi rutin mingguan beberapa asatidz juga tidak hadir tanpa ada izinnyang jelas.

Untuk mengatasi pemasalahan ini pimpinan pesantren harus membuat kebijakan dan mengarahkan orang-orang yang secara struktural berada di bawahnya untuk meningkatkan etos kerjanya. Karena seitap aktivitas pesantren tidak bisa lepas dari daya guna manusia. Maka dari itu, kepemimpinan pendidikan di pesantren berperan sangat penting dalam rangka mengarahkan dan menggerakkan organisasi di pesantren untuk mencapai tujuan yang diharapkan. kepemimpinan pendidikan adalah segenap kegiatan dalam usaha mempengaruhi personal di lingkungan pendidikan pada situasi tertentu agar mereka melalui usaha kerjasama, mau bekerja dengan penuh tanggung jawab dan ikhlas demi tercapainya tujuan pendidikan yang telah ditetapkan ${ }^{7}$.

Kepemimpinan dapat dimaknai sebagai kemampuan untuk menggerakkan, memengaruhi, memotivasi, mengajak, mengarahkan, menasehati, membina, membimbing, melatih, menyuruh, memerintah, melarang, dan bahkan menghukum (jika diperlukan ) dengan maksud agar manusia sebagai bagian dari organisasi mau bekerja dalam rangka mencapai tujuan dirinya sendiri maupun organisasi secara efektif dan efisien. Pengertian ini menunjukkan bahwa kepemimpinan terdapat tiga unsur yaitu pemimpin ( leader), anggota (leader), dan situasi

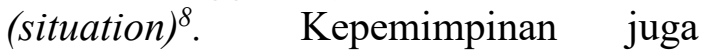
mempunyai fungsi mengusahakan keefektifan organisasi dengan mengusahakan etos kerja yang positif

\footnotetext{
${ }^{7}$ Ara Hidayat, "Pengelolaan Pendidikan (Konsep, Prinsip, dan Aplikasi dalam Mengelola sekolah dan Madrasah)," Universitas Pendidikan Indonesia (2012).

8 Habibur Rahman dan Raima Selviana, "KEPEMIMPINAN DAN PENDIDIKAN
}

kepada orang-orang yang secara struktural harus dipimpin 9

Dari uraian di atas dapat disimpulkan bahwa seorang pimpinan mempunyai tugas dan tanggung jawab untuk meningkatkan etos kerja orangorang yang secara struktural berada di bawahnya. hal ini dikarenakan seorang pimpinan mempunyai fungsi untuk mengusahakan keefektifan organisasi. Kewajiban pimpinan untuk memperhatikan etos kerja bawahannya berlaku untuk seluruh lembaga pendidikan tidak terkecuali pesantren khususnya pondok pesantren Ibnul Qoyyim Putra Yogyakarta. Terjadi penurunan etos kerja di kalangan pengasuh atau asataidz pondok pesantren Ibnul Qoyyim Putra. Hal ini dikarenakan para Asatidz kurang bersungguh-sungguh dalam melaksanakan tugas yang diberikan. Asatidz merupakan istilah Jama' yang digunakan untuk menyebut pengasuh di pondok pesantren Ibnul Qoyyim putra. Sedangkan secara personal pengasuh di pondok pesantren Ibnul Qoyyim putra oleh para santri dipanggil dengan sebutan Ustadz.

Adapun pengabdian merupakan status untuk para asatidz yang mendapatkan tugas untuk mengurusi segala hal yang berkaitan tentang kepesantrenan. Asatidz pondok pesantren Ibnul Qoyyim Putra direkrut dari alumni pondok pesantren Ibnul Qoyyim putra sendiri. Ada perbedaan antara asatidz pengabdian dengan staf pengajar ataupun karyawan di pondok pesantren Ibnul Qoyyim Putra. Dalam perekrutannya asatidz pengabdian tidak menggunakan syarat kesarjanaan sedangkan untuk menjadi staf pengajar dibutuhkan syarat kesarjanaan sesuai

ISLAM," Competence: Journal of Management Studies 12, no. 2 (2019).

9 Hidayat, "Pengelolaan Pendidikan (Konsep, Prinsip, dan Aplikasi dalam Mengelola sekolah dan Madrasah)." 
dengan bidangnya. Walaupun pada prakteknya ada juga asatidz pengabdian yang diminta menjadi staf pengajar karena dinggap mumpuni.

Untuk staf pengajar dan karyawan kompensasinya telah ditetapkan namun untuk asatidz pengabdian tidak ada aturan khusus mengenai kompensasi hanya saja pihak pesantren berusaha untuk memberikan kompensasi terbaik untuk Asatidz pengabdian. Dalam proses kepemimpinan di pondok pesantren Ibnul Qoyyim Putra pemegang kebijakan tertinggi adalah direktur KMI (Kulliyatul Mu'allimin Al- Islamiyah) dan wakil direktur KMI. Adapun kepemimpinan kyai di pondok pesantren Ibnul Qoyyim putra diposisikan sebagai kepemimpinan yang bersifat spiritual. Kyai tidak dibebani tanggung jawab manajemen pesantren namun nasehat serta petuahnya dijadikan pertimbangan penting untuk melaksanakan kebijakan-kebijakan pesantren. Kyai pondok pesantren Ibnul Qoyyim sekaligus pendiri adalah beliau K.H.R Hisyam Syafi'i.

Setelah K.H.R Hisyam Syafi'i meninggal, terjadi pergeseran fungsi kyai. Kyai yang pada awalnya diposisikan sebagai kepemimpinan spiritual, kini mempunyai wewenang dan tanggung jawab dalam struktur kelembagaan pesantren dan juga dalam menentukan kebijakan-kebijakan manajerial pesantren termasuk berkaitan dengan peningkatan etos kerja asatidz pengabdian. dikatakan demikian karena saat ini amanah sebagai direktur dan tanggung jawab sebagai kyai dipegang oleh inividu yang sama Sehingga setiap kebijakan yang beliau buat tidak bisa dipisahkan antara kebijakan direktur ataupun kebijakan

10 Joni Maulindar dan Annas Setiawan Prabowo, "Aspek Kepemimpinan Dalam Penyelarasan Strategi Bisnis TI/ SI,” Jurnal Duta.Com 4 (2019).

${ }^{11}$ Naufal Yahya, "Definisi Kepemimpinan Dalam Organisasi," Kabar Pasar Jurnal ilmu Ekonomi 1, no. 1 (2019). kyai, melainkan merupakan satu kesatuan.

\section{Kajian Pustaka \\ 1. Kepemimpinan}

Setiap organisasi maupun lembaga tentunya harus memiliki seorang pemimpin. Pemimpin mempunyai tugas untuk melaksanakan kegiatan kepemimpinan maupun manajamen agar sistem yang ada dalam organisasi bisa berjalan dengan sehat. Ketika sistem telah berjalan dengan baik maka suatu organisasi akan mengalami perkembangan dengan baik. kepemimpinan adalah kemampuan yang dimiliki seseorang untuk mempengaruhi orang lain untuk mencapai suatu tujuan ${ }^{10}$.

Proses memberi pengaruh terwujud dalam proses interaksi antar satu pihak yang memimpin dengan pihak yang dipimpin ${ }^{11}$. Sutisna dalam Mulyasa juga menjelaskan bahwa kepemimpinan merupakan sebuah tahapan memberi pengaruh pada orang lain atau kelompok sebagai usah untuk mencapai tujuan yang telah dicanangkan ${ }^{12}$. Untuk dapat mampu memberi pengaruh, kepemimpinan memerlukan konsep relasi (relational concept ) antara individu yang menjadi pemimpin dengan anggota yang dipimpinnya. Relasi yang dibangun dalam proses kepemimpinan mempunyai perbedaan dan ciri khas masing-masing dalam sebuah organisasi. Pandangan dan aspek budaya dalam sebuah organisasi dapat mempengaruhi jalannya sebuah kepemimpinan ${ }^{13}$.

Benang merah yang dapat ditarik adalah bahwa kepemimpinan selalu melibatkan unsur pemimpin, pengikut, dan konteks. Ketiadaan salah satu dari ketiga unsur tersebut akan

12 E Mulyasa, "Manajemen Berbasis Madrasah: Konsep, Strategi, dan Implementasi," Bandung: PT Remaja Rosdakarya (2007).

13 Arzu Akkaya, "Theories of educational management and leadership," Educational Review 73, no. 6 (2021). 
menghilangkan esensi pemimpin itu sendiri. Efektifitas kepemimpinan dapat dilihat dari proses hubungan dengan anggotanya hingga seorang pemimpin mampu mengajak anggotanya untuk bergerak menuju visi yang telah disepakati.

Terdapat tiga tipe kepemimpinan dalam proses influensi seorang pemimpin terhadap anggota-anggota yang dikelolalnya. Secara garis besar terdapat tipe kepemimpinan yaitu otokratis/otorites, demokratis, dan kendali bebas (laizes Faire). Ketiga tipe kepemimpinan tersebut muncul dari latar belakang pemimpin yang berbeda-beda. Tipe tersebut melekat kepada seorang pemimpin berdasarkan kondisi psikologis, latar belakang pendidikan, maupun kondisi sosial budaya tempat dia bertumbuh ${ }^{14}$. Tipe kepemimpianan otoriter cenderung dipandang negatif. Hal ini dikarenakan pemimpin menggunakan egoismenya untuk menentukan suatu hal. Dengan egoismenya, pemimpin melihat peranannya sebagai sumber segaa sesuatu dalam kehidupan organisasional ${ }^{15}$. Tipe kepemimpinan otoriter disebut juga tipe kepimpinan authoritarian $^{16}$. Dalam kepemimpinan otoriter, dominasi yang berlebihan dapat menghidupkan oposisi atau menimbulkan sifat apatis, atau sifat-sifat pada anggotaanggota kelompok pemimpinnya.

Kepemimpinan demokratis bertujuan pada manusia, dan memberikan bimbingan yang efisien kepada para pengikutnya. Semua tugas yang ada terkoordinasi antar pimpinan dan

${ }^{14}$ Hidayatus Syarifah, "PENDIDIKAN DALAM KELUARGA," Raudhah Proud To Be Professionals: Jurnal Tarbiyah Islamiyah 2, no. 1 (2017).

15 Besse Mattayang, "TIPE DAN GAYA KEPEMIMPINAN: SUATU TINJAUAN TEORITIS," JEMMA | Journal of Economic, Management and Accounting 2, no. 2 (2019).

16 AGUS PURWANTO et al., "Pengaruh Gaya Kepemimpinan Tansformational, Authentic, bawahan, dengan penekanan pada tanggung jawab individu dan kerja sama yang baik. Kekuatan dari tipe kepemimpinan demokratis tidak terletak pada individu pimpinan melainkan pada partisipasi aktif dari kelompok. Kepemimpinan demokratis menghargai potensi setiap individu maupun mendengarkan nasehat dan sugesti dari bawahan. Juga bersedia mengakui keahlian para spesialis dengan bidangnya masing- masing mampu memanfaatkan kapasitas setiap anggota seefektif mungkin pada saat-saat dan kondisi yang tepat. Kepemimpinan demokratis sering juga disebut sebagai kepemimpinan group developer ${ }^{17}$.

Antitesis dari kepemimpinan otoriter adalah kepemimpinan kendali bebas.

Dalam tipe kepemimpinan ini sebenarnya pemimpin tidak memberikan kepemimpinannya, dia membiarkan bawahannya berbuat sekehendaknya. Pemimpin sama sekali tidak memberikan kontrol dan koreksi terhadap bawahannya. Pembagian tugas dan kerja diserahkan sepenuhnya pada bawahannya tanpa petunjuk atau saran-saran dari pemimpin. Tingkat keberhasilan organisasi atau lembaga semata-mata disebabkan oleh kesadaran dan dedikasi beberapa anggota kelompok, dan bukan karena pengaruh dari pemimpin. Struktur organisasinya tidak jelas dan kabur, segala kegiatan dilakukan tanpa rencana dan tanpa pengawasan dari pimpinan ${ }^{18}$. Pemimpin dengan tipe Laizzez Faire merupakan simbol dan biasanya tidak memiliki keterampilan teknis, sebab

Authoritarian, Transactional Terhadap Kinerja Guru Madrasah Aliyah di Tangerang," journal EVALUASI 4, no. 1 (2020).

17 Maulana Akbar Sanjani, "KEPEMIMPINAN DEMOKRATIS KEPALA SEKOLAH," Jurnal Serunai Administrasi Pendidikan 7, no. 1 (2019).

18 Sri Winarsih, "Gaya Kepemimpinan Kepala Sekolah dalam Meningkatkan Kinerja Guru," International Conference of Moslem Society 2 (2018). 
duduknya sebaai pemimpin tidak diperoleh melalui sistem atau tata cara yang berlaku.

\section{Etos Kerja}

Makna etos kerja sedikit banyak telah disinggung dalam latar belakang. Etos berasal dari bahasa Yunani (ethos) yang memberikan arti sikap, kepribadian, watak, karakter, serta keyakinan atas sesuatu. Sikap ini tidak saja dimiliki oleh individu, tetapi juga oleh kelompok bahkan masyarakat ${ }^{19}$. Etos dapat dimaknai sebagai pemahaman dan keyakinan terhadap nilai-nilai yang secara mendasar mempengaruhi kehidupan, menjadi prinsip-prinsip pergerakan, dan cara berekspresi yang $\operatorname{khas}^{20}$.

Etos kerja merupakan watak khas yang tampak dari luar dan terlihat oleh orang lain. Menurut Geertz, etos merupakan sikap dasar manusia terhadap diri dan dunia yang dipancarkan hidup. Etos adalah aspek evaluatif yang bersifat menilai. Soerjono Soekanto (1983) mengartikan etos antara lain : a. Nilai-nilai dan ide-ide dari suatu kebudayaan, dan b. Karakter umum suatu kebudayaan ${ }^{21}$.

Menurut Nurcholis Majid (1995) etos berasal dari bahasa Yunani, artinya watak atau karakter dan sikap, kebiasaan serta kepercayaan dan seterusnya yang bersifat khusus tentang seorang individu atau sekelompok manusia. Dan dari kata etos terambil pula perkataan "etika" yang merujuk pada makna "akhlak" atau bersifat akhlaqy, yaitu kualitas esensial seseorang atau suatu kelompok termasuk suatu bangsa.

19 Toto Tasmara, "Etos kerja Pribadi Muslim," Angewandte Chemie International Edition, 6(11), 951-952. (2013).

20 Iman Setya Budi, "Pengaruh Religiusitas terhadap Etos Kerja Pedagang Banjar di Pasar Sudimampir Banjarmasin," Jurnal Ekonomi Syariah dan Hukum Ekonomi Syariah 5, no. 2 (2019).

${ }^{21}$ Ahmad Janan Asifudin, "Manajemen Pendidikan untuk Pondok Pesantren," Manageria: Jurnal Manajemen Pendidikan Islam 1, no. November (2016).
Etos juga berarti jiwa khas suatu kelompok manusia yang daripadanya berkembang pandangan bangsa itu sehubungan dengan baik dan buruk, yakni etika $^{22}$. Sedangkan kerja dapat diartikan sebagai kegiatan terencana dan membutuhkan pemikiran khusus yang dilakukan seseorang untuk mencapai tujuannya ${ }^{23}$. Pekerjaan yang dilakukan tidak hanya karena pelaksanaan kegiatan itu sendiri menyenangkan, melainkan karena kesungguhan mencapai hasil yang kemudian berdiri sendiri atau sebagai benda, karya, tenaga dan sebagainya ${ }^{24}$.

Setiap manusia memiliki spirit (roh) keberhasilan, yaitu motivasi murni untuk meraih dan menikmati keberhasilan. Roh inilah yang menjelma menjadi perilaku yang khas seperti kerja keras, disiplin, teliti, tekun, integritas, rasional, bertanggung jawab dan sebagainya. Lalu perilaku yang khas ini berproses menjadi kerja yang positif, keratif, dan produktif. Lalu perilaku yang khas ini berproses menjadi kerja yang positif, kreatif, dan produktif.

Terdapat empat pilar teori utama tentang kesuksesan. Keempat elemen itu lalu dikonstruksikan dalam sebuah konsep besar yang disebut sebagai "Catur Dharma Mahardika" yang artinya Empat Darma Keberhasilan utama yaitu 1) Mencetak prestasi dengan motivasi superior; 2) membangun masa depan dengan kepemimpinan visioner; 3) menciptakan nilai baru dengan inovasi kratif; 4) meningkatkan mutu dengan keunggulan insani. Keempat darma

\footnotetext{
${ }^{22}$ Raihanatul Jannah, "ETOS KERJA DAN POLA PENDIDIKAN PADA KELUARGA PENDULANG INTAN TRADISIONAL (STUDI KASUS DI KECAMATAN CEMPAKA KOTAMADYA BANJARBARU)," Jurnal Ta'lim Muta'allim 1, no. 1 (2015).

${ }^{23}$ Panji Anoraga dan Djoko Sudantoko, "Koperasi, Kewirausahaan dan Usaha Kecil," Rineka Cipta, 2002.

${ }^{24}$ Ibid.
} 
tersebut kemudian dirumuskan menjadi delapan elemen etos kerja sebagai berikut $^{25}$ : a) Kerja adalah rahmat, karena pekerjaan merupakan anugerah dari tuhan; b) Kerja adalah amanah, kerja merupakan titipan berharga yang harus dilaksanakan dengan penuh tanggung jawab; c) Kerja adalah panggilan, kerja merupakan suatu darma yang sesuai dengan panggilan jiwa sehingga bisa dilaksanakan dengan penuh integritas; d) Kerja adalah aktualisasi, kerja adalah sarana untuk mencapai hakikat manusia yang tertinggi; e) Kerja adalah ibadah, bekerja merupakan bentuk bakti dan ketakwaan kepada tuhan; f) Kerja adalah seni, kesadaran ini akan membuat seseorang melaksanakan kerja ddengan perasaan senang; g) Kerja adalah kehormatan, seremeh apapun sebuah pekerjaan itu adalah sebuah pekerjaan. Jika bisa menjaga kehormatan dengan baik, maka kehormatan lain yang lebih besar akan datang; h) kerja adalah adalah pelayanan, apapun pekerjaan yang dilakukan semuanya dimaknai sebagi pengabdian kepada sesama.

\section{Motivasi}

Motivasi merupakan suatu proses yang dilandasi oleh suatu dorongan. Dorongan inilah yang kemudian disebut sebagai kebutuhan. Stephen P. Robbin (2003) mendefinisikan motivasi sebagai "kesediaan untuk mengeluarkan tingkat upaya yang tinggi untuk tujuan organisasi yang dikondisikan oleh kemampuan upaya itu dalam memenuhi beberapa kebutuhan individual ${ }^{26}$. Kebutuhan atau need sebagai kondisi awal merupakan sebuah istilah yang menunjukkan adanya hal-hal yang perlu dipenuhi oleh diri. Sesuatu menjadi kebutuhan bagi

\footnotetext{
${ }^{25}$ Jansen Sinamo, "Delapan Etos Kerja Profesional : Navigator Anda Menuju Sukses," Bogor: Grafika Mardi Yuana. 20, no. 5 (2005).

26 Wahyu Dwi Haryanto, "PENGARUH STRESS KERJA DAN MOTIVASI TERHADAP KEPUASAN KERJA ( Studi pada Perawat RSUD Kota Semarang )," Pengaruh Stres Kerja Dan
}

seseorang jika berdasarkan penilaian dirinya merupakan suatu hal yang dinilai penting atau harus dipenuhi. Semakin tinggi tingkat penilaiannya semakin tinggi pula tingkat kebutuhan yang akan mendorong semakin tinggi perilaku pemenuhannya.

Menurut Maslow (1954) dalam Cepi Triyatna, Motivasi yang tumbuh dari dalam diri seseorang tergantung pada keberadaan seseorang. Terdapat tingkatan atau hierarki tentang kebutuhan manusia. Terentang dari tingkatan paling bawah sampai tingkatan paling atas. Semakin tinggi keberadaan seseorang dalam hierarki tersebut, semakin tinggi pula motivasinya untuk melakukan sesuatu yang besar demi mencapai sebuah prestasi yang dapat membanggakan dirinya dan/ atau organisasinya. Menurut Maslow, kebutuhan seseorang itu tergantung dari kebutuhan yang paling bawah sampai kebutuhan yang paling tinggi. Ada lima hierarki kebutuhan bagi manusia, yaitu kebutuhan dasar, keamanan, sosial, penghargaan, dan aktualisasi diri ${ }^{27}$.

Kajian motivasi menurut Maslow ini terus berkembang seiring dengan perkembangan situasi dan kondisi yang menyertai dunia organisasi. Pada tahun 1999 Maslow mengembangkan teori hierarki kebutuhan menjadi delapan tahap dengan menambahkan kebutuhan untuk mengetahui dan memahami, kebutuhan estetika.keindahan, dan kebutuhan transendensi diri. Kedelapan tahapan tersebut secara hierarki sebagai berikut : kebutuhan fisik, kebutuhan keamanan, kebutuhan rasa memiliki dan cinta, kebutuhan penghargaan, kebutuhan untuk mengetahui dan memahami, kebutuhan

\footnotetext{
Motivasi Terhadap Kepuasan Kerja (Studi Pada perawat RSUD Kota Semarang), no. 1 (2014).

27 Tri Andjarwati, "Motivasi dari Sudut Pandang Teori Hirarki Kebutuhan Maslow, Teori Dua Faktor Herzberg, Teori X Y Mc Gregor, dan Teori Motivasi Prestasi Mc Clelland," jmm17 2, no. 01 (2015).
} 
keindahan, kebutuhan aktualisasi diri, dan kebutuhan transendensi ${ }^{28}$.

\section{Metode Penelitian}

Secara garis besar penelitian yang akan dilaksanakan adalah peneitian yang bersifat kualitatif. Penelitian kualitatif merupakan penelitian yang menggunakan pendekatan naturalistik untuk mencari dan menemukan pengertian atau pemahaman tentang fenomena dalam suatu latar yang khusus. Penelitian kualitatif juga diartikan sebagai penelitian yang berupaya membangun pandangan orang yang diteliti secara rinci serta dibentuk dengan kata-kata dan gambaran holistic. Adapun penelitian yang akan dilakukan menggunakan pendekatan fenomenologi.

Pendekatan

fenomenologi merupakan pendekatan yang di dalamnya peneliti mengidentifikasi hakikat pengalaman manusia tentang suatu fenomena tertentu. dengan pendekatan ini, peneliti mengkaji sejumlah subjek dengan terlibat secara langsung dan relatif lama di dalamnya untuk mengembangkan polapola dan relasi makna.

Dalam penelitian ini peneliti memilih subjek penelitian menggunakan teknik Purposeful Sampling yaitu memilih subjek penelitian dengan ciri-ciri yang sesuai dengan tujuan penelitian yang dilakukan $^{29}$. Maksudnya adalah subjek penelitian memahami, mengalami, dan mengetahui dengan baik topik penelitian yang sedang dilakukan. Adapun subyek dalam penelitian ini adalah Direktur KMI, Wakil direktur KMI, dan dua belas orang asatidz pengabdian pondok pesantren Ibnul Qoyyim Putra. Untuk mendapatkan informasi yang mendalam dari para narasumber, peneiti menggunakan tiga metode yaitu

\footnotetext{
${ }^{28}$ Andita Ratih et al., "Transendensi Diri Pekerja Sosial (Studi kasus tentang transendensi diri pekerja sosial di Unit Pelaksana Tugas Pusat Kesejahteraan Sosial Dinas Sosial Kota Bandung)," Share : Social Work Journal 10, no. 1 (2020).
}

wawancara mendalam (indepth interview), observasi, dan telaah dokumen. Kemudian data yang diperoleh akan dilakukan validitas dan keabsahan datanya menggunakan teknik triangulasi seumber, triangulasi metode, triangulasi dengan peneliti, dan triangulasi dengan teori.

\section{Hasil dan Pembahasan \\ Etos Kerja Asatidz Pengabdian Pondok Pesantren Ibnul Qoyyim Putra}

Dewasa ini, pembahasan tentang etos kerja menjadi semakin penting. Hal ini dikarenakan dilema kerja semakin kompleks. Terlebih etos kerja pengasuh di pesantren, tidak terkecuali pondok pesantren Ibnul Qoyyim putra. Karena input maupun output dari pesantren adalah manusia yang harus dikembangkan potensi-potensinya. Etos kerja merupakan refleksi dari sikap hidup yang mendasar, maka etos kerja pada dasarnya juga merupakan cerminan dari pandangan hidup yang berorientasi pada nilai yang berdimensi pada transenden.

Nilai-nilai transeden itu akan menjadi dasar bagi pengembangan spiritualitas yang sangat diperlukan sebagai kekuatan yang membentuk suatu kepribadian yang menentukan kualitas eksistensial dalam hidupnya. Tugas Pokok seorang Ustadz pengabdian adalah menjadi pembimbing kamar yang tinggal di kamar bersama para santri dan memegang satu jabatan dalam struktur organisasi kepengasuhan. Karena berada satu kamar dengan para santri, seorang Ustadz haruslah bisa memberi contoh yang baik kepada para santri.

Untuk menjadi panutan ataupun teladan untuk para santri, seorang Ustadz akan bersikap santun, sabar, rendah hati,

\footnotetext{
${ }^{29}$ Harsh Suri, "Purposeful sampling in qualitative research synthesis," Qualitative Research Journal 11, no. 2 (2011).
} 
dan memiliki emosi yang stabil dalam melaksanakan tugas-tugasnya. Sifat-sifat tersebut merupakan penggambaran dari seseorang yang mempunyai karakteristik etos kerja yang baik. Sifat-sifat tersebut juga termasuk dalam keahlian interpersonal seseorang sama seperti sifat loyal yang telah disinggung di atas.

Seorang wali kamar juga memposisikan diri sebagai orang tua, kakak, maupun teman agar para santri merasa nyaman tinggal di pesantren. Ketika seorang Ustadz yang mendapat tanggung jawab sebagai wali kamar memposisikan dirinya sebagai orang tua, kakak, ataupun sahabat untuk santrisantrinya artinya dia menganggap bahwa santri-santri yang berada di kamarnya merupakan amanah yang dititipkan kepadanya dan harus dibina serta diperlakukan sebaik mungkin. Artinya tugas atau pekerjaan sebagai wali kamar adalah sebuah amanah yang harus dilaksanakan sebaik mungkin dan penuh tanggung jawab. Hal ini sesuai dengan apa yang dipaparkan oleh sinamo (2005) yang dikutip oelh Donni. Bahwa ada empat Darma keberhasilan utama yang kemudian dirumuskan menjadi delapan etos kerja yang salah satunya adalah kerja ataupun tugas yang diemban merupakan amanah ataupun titipan berharga yang harus dilaksanakan dengan penuh tanggung jawab.

Selain mendapatkan tugas sebagai wali kamar, Asatidz Pengabdian juga diberi tanggung jawab memegang satu bagian dalam struktur organisasi kepengasuhan. Setiap pengabdian melaksanakan tugasnya sesuai bagian yang menjadi tanggung jawabnya. Ada beberapa bagian dalam struktur organisasi kepengasuhan yaitu koordinator pengasuhan, sekretaris, kesantrian, Pembina bahasa, Pembina Pramuka (mabikori), Pembina ekstrakurikuler, bagian kesehatan dan lingkungan, bagian tahfidzul Qur'an, bagian tarbiyah dan ta'lim, bagian sarana dan pra sarana.
Dua tanggung jawab yang diemban oleh Asatidz pengabdian sebagai wali kamar maupun bagaian kepengasuhan megharuskan mereka untuk bisa membagi waktunya secara disiplin. Baik untuk urusan pribadi maupun urusan-urusan pesantren itu sendiri. Terlebih beberapa Asatidz pengabdian juga menempuh pendidikan di perguruan tinggi. Menurut Ustadz Hendriana Wijaya S.Hum, agar bisa menyeimbangkan antara tugas-tugas pesantren dengan urusan pribadi beliau membuat jadwal agar tidak terjadi benturan antara tugas pesantren dann urusan-urusan pribadi.

Membuat Run down merupakan bentuk usaha yang dilakukan oleh Ustadz Hendriana Wijaya agar bisa disiplin dalam melaksanakan tugas-tugas pesantren. Sehingga setiap tugas yang beliau emban bisa terlaksana dengan maksimal. Sikap disiplin merupakan sikap positif yang menunjukkan kualitas etos kerja seseorang. Dengan sikap disiplin seseorang bisa melaksanakan tugasnya tepat waktu dan hasilnya maksimal.

Namun, dalam beberapa kondisi, Asatidz pengabdian di Pondok Pesantren Ibnul Qoyyim putra mengalami penurunan etos kerja. Penyebab dari menurunnya etos kerja asatidz pengabdin adalah kejenuhan terhadap tugas-tugas rutin yang dilakukan setiap waktu

Kejenuhan dalam melaksanakan tugas sangat mungkin terjadi. hal tersebut disebabkan karena tugas yang dilaksanakan setiap harinya selalu sama. Ditambah lagi tugas dari Asatidz pengabdian di pondok pesantren Ibnul Qoyyim PUTRA berlangsung selama 24 jam penuh.

Adapun dari pengamatan pimpinan, etos kerja asatidz pengabdian sudah cukup baik. Karena para asatidz pengabdian pennempatan tugasnya sudah disesuaikan dengan kemampuan masing-masing. Namun ada beberapa catatan dari pimpinan berkaitan dengan kinerja dari 
asatidz pengabdian. Asatidz Pengabdian perlu lebih memperhatikan lebih cermat berkaitan permasalahan-permasalahan di pesantren seperti kebersihan maupun ketertiban santri serta memperbaiki komunikasi antar asatidz agar kegiatankegiatan yang dilaksanakan tidak saling berbenturan baik dari segi waktu maupun pendanaan.

\section{Faktor yang Mempengaruhi Etos Kerja Asatidz Pengabdian}

Ada beberapa faktor yang mempengaruhi etos kerja asatidz pengabdian yaitu: Pertama, motivasi. Menurut Maslow (1954) dalam Cepi Triyatna, Motivasi yang tumbuh dari dalam diri seseorang tergantung pada keberadaan seseorang. Terdapat tingkatan atau hierarki tentang kebutuhan manusia. Terentang dari tingkatan paling bawah sampai tingkatan paling atas. Semakin tinggi keberadaan seseorang dalam hierarki tersebut, semakin tinggi pula motivasinya untuk melakukan sesuatu yang besar demi mencapai sebuah prestasi yang dapat membanggakan dirinya dan/ atau organisasinya. Jika ditelaah menggunakan hierarki kebutuhan Maslow, tingkatan motivasi asatidz untuk melaksanakan pengabdian berada pada tahapan transendensi diri.

Transendensi diri dimaknai sebagai pelepasan terhadap ego. Artinya dalam melaksanakan tugas sebagai pengabdian bukan bertujuan untuk kepuasan diri sendiri namun ditujukan untuk turut serta membantu pengembangan pesantren. Asatidz di pondok pesantren Ibnul Qoyyim Putra menjadikan tujuan pengabdiannya sebagai bentuk terima kasih kepada pesantren. Karena asatidz pengabdian di pondok pesaantren Ibnul Qoyyi putra adalah alumni pondok pesantren Ibnul Qoyyim putra itu sendiri. Dorongan ataupun motivasi untuk berterima kasih kepada pesantren secara tidak langsung mempengaruhi etos kerja asatidz pengabdian menjadi lebih baik.
Karena berterima kasih identic dengan balas budi. Ketika seseorang diperlakukan baik maka dia akan membalas kebaikan tersebut dengan baik ataupun lebih baik. Demikian halnya dengan para asatidz yang telah pendidikan terbaik dari pesantren akan melakukan hal yang terbaik juga untuk pesantren.

Karena asatidz pengabdian di pondok pesantren Ibnul Qoyyim putra merupakan alumni, ada rasa memiliki yang tinggi terhadap pesantren. Sehingga merasa perlu untuk ambil bagian untuk memajukan pesantren. Rasa memiliki dan dorongan untuk memajukan pondok pesantren Inilah yang menjadi dasar etos kerja yang baik. Kedua, faktor ekonomi.

Kesejahteraan juga sangat mempengaruhi etos kerja yang tumbuh dan berkembang. Negara maju dan makmur biasanya memiliki masyarakat yang memiliki etos kerja tinggi sehingga mendorong negara tersebut mencapai kesuksesan. Jika dilihat melalui lingkup yang lebih sederhana, kesejahteraan dalam hal ini adalah gaji ataupun honor yang diterima oleh asatidz pengabdian. Walaupun pada dasarnya asatidz tidak mendapat gaji ataupun honor, namun pihak pesantren tetap mengusahakan sebagai bentuk terima kasih kepada asatidz pengabdian atas kinerja yang dilakukan Berkaitan tentang pemberian honor, sedikit banyak mempengaruhi kinerja asatidz pengabdian. Mengingat asatidz pengabdian kebanyakan masih melaksanakan pendidikan di perguruan tinggi.

Adanya Pemberian honor kepada asatidz pengabdian sedikit banyak meningkatkan etos kerja. Namun tujuan utama para asatidz melakukan tugas-tugas pesantren bukan semata untuk itu melainkan sebagai bagian dari upaya memajukan pesantren. Adapun honor yang didapat merupakan bonus yang diberikan oleh pesantren. 
Ketiga, lingkungan kerja pesantren. Etos kerja seorang ustadz pengabdian mempunyai keterikatan satu sama lain. hal ini dikarenakan sudah ada ikatan yang kuat antara asatidz pengabdian yang satu dengan lainnya. Mengingat seluruh asatidz pengabdian merupakan alumni pondok pesantren Ibnul Qoyyim putra itu sendiri. Sehingga tahu betul seluk beluk tentang pesantren dan tingkah laku serta watak antara seorang ustad pengabdian dengan ustad pengabdian yang lain. Ketika etos kerja seorang ustadz pengabdian baik, maka hal tersebut akan berpengaruh baik pada asatidz yang lain. terlebih lagi etos kerja positif yang ditunjukkan oleh ustadz pengabdian yang lebih senior akan menjadi teladan ataupun contoh terbaik terhadap asatidz-asatidz pengabdian yang berada di bawahnya.

Ketika etos kerja positif seorang ustadz pengabdian bisa mempengaruhi etos kerja ustadz pengabdian yang lain, etos kerja yang rendah juga berpengaruh kepada yang lain. Ketika seorang ustadz pengabdian sedang berusaha menjalankan tugas dengan sebaik mungkin, namun ustadz yang lain hanya duduk santai tanpa mempedulikan kinerja temannya hal tersebut dapat mengganggu etos kerja ataupun keikhlasan yang sudah berusaha dibangun.

Namun ustad Agus Sriwanto S.Pd mempunyai pendapat yang berbeda terkait pengaruh etos kerja rekan asatidz pengabdian terhadap etos kerja beliau. Beliau fokus kepada tugas dan tanggung jawab yang diembannya sehingga tidak begitu memperhatikan bagaimana etos kerja asatidz pengabdian yang lain. Karena ketika mencampuri kinerja asatidz yang lain beliau khawatir tugas dan tanggung jawabnya tidak terselesaikan. Beliau hanya sebatas mengingatkan kepada ustad pengabdian yang terlihat menurun etos kerjanya.
Keempat, agama. Ibnul Qoyyim putra merupakan lembaga pendidikan berbasis pesantren yang mempunyai visi membentuk generasi mu'min, muallim, muballigh, mujahid yang mukhlis. Untuk itu dalam pendidikannya, pondok pesantren Ibnul Qoyyim putra menanamkan nilai-nilai keislaman yang tinggi agar para santri bisa memahaminya secara kaffah. Hal tersebut tidak hanya berlaku untuk para santri saja. Namun juga berlaku kepada seluruh asatidz pengabdian. Sehingga nilai-nilai keislamaan yang ditanamkan juga mempengaruhi etos kerja para asatidz pengabdian. Nilai-nilai keislaman yang dimaksud adalah keikhlasan dalam melaksanakan tugas pengabdian di pesantren. Karena dengan keikhlasan dalam melaksanakan setiap tugas akan menjadi berkah tersendiri untuk asatidz pengabdian. Nama pondok pesantren Ibnul Qoyyim putra diambil dari nama seorang ulama besar dizamannya yaitu imam Ibnu Qoyyim Al-Jauziyah. pokok-pokok ajaran yang disampaikan oleh imam Ibnul Qoyyim Al-Jauziyah berkaitan tentang hati. Sehingga dalam setiap kesempatan beliau selalu memeberi nasehat kepada para asatidz pengabdian untuk selalu menyempurnakan hati agar dalam melaksanakan tugas-tugas pengabdian dapat dilaksanakan dengan penuh keikhlasan.

\section{Upaya Pimpinan Dalam Meningkatkan Etos Kerja Asatidz Pengabdian di Pondok Pesantren Ibnul Qoyyim Putra}

Setiap organisasi maupun lembaga tentunya harus memiliki seorang pimpinan. Pimpinan mempunyai tugas untuk melaksanakan kegiatan kepemimpinan maupun manajemen agar sistem yang ada dalam organisasi bisa berjalan. Hal tersebut juga berlaku di pondok pesantren Ibnul Qoyyim putra. salah satu aspek yang harus diperhatikan pimpinan dalam melaksanakan proses kepemimpinan adalah etos kerja dari 
bawahannya yang dalam hal ini adalah asatidz pengabdian. Untuk itu pimpinan harus mempunyai perhatian terhadap peningkatan etos kerja. Berikut ini adalah peran pimpinan pondok pesantren Ibnul Qoyyim Putra dalam meningkatkan etos kerja asatidz pengabdian :

Memberikan Apresiasi Kepada Asatidz yang Etos Kerjanya Baik

Razik dan Swanson (1995) menjelaskan bahwa seorang pimpinan haruslah mengetahui bagaimana membangkitkan inspirasi maupun etos kerja yang baik terhadap pengikut mereka. Adapun bentuk membangkitkan inspirasi yang dilakukan oleh pimpinan pondok pesantren Ibnul Qoyyim putra adalah memberikan apresiasi Untuk asatidz yang mempunyai etos kerja baik, pimpinan pondok pesantren Ibnul Qoyyim putra selalu memberikan apresiasi. Namun apresiasi yang diberikan tidak selalu berbentuk materi.

Apresiasi yang paling sederhana yang diberikan pimpinan kepada adalah ucapan terima kasih kepada asatidz karena telah melaksanakan tugas pesantren dengan sepenuh hati. Menurut ustad Muhammad Aka ucapan terima kasih dari pimpinan sudah cukup bagi beliau karena menurut beliau segala sesuatu yang dilakukan di pesantren bukan untuk mendapatkan apresiasi dari pimpinan melainkan untuk berdakwah.

Bentuk apresiasi yang lain terhadap asatidz yang etos kerjanya baik adalah dipertahankan untuk tetap mengabdi di pesantren. Ketika asatidz pengabdian dipertahankan oleh pimpinan artinya pengabdian tersebut telah mendapatkan kepercayaan yang penuh dari pimpinan. Asatidz yang etos kerjanya baik juga ditambah tugas dan tanggung jawabnya. Menurut ustadz Ade Kriyadi SW ditambah tugas dan tanggung jawabnya bisa dianalogikan dengan kenaikan pangkat jika berada di perusahaan pada umumnya.
Apa yang disampaikan oleh ustadz Ade Kriadi ini menggambarkan bahwa penambahan tugas yang diberikan oleh pimpinan dan dipertahankan menjadi pengabdian bukanlah menjadi beban. Para Asatidz pengabdian menganggapnya sebagai sebuah apresiasi terhadap tugas-tugas yang telah dilaksanakan. Dengan ditambahnya tugas dan tanggung jawab serta dipertahankan menjadi seorang pengabdian, maka para asatidz mempunyai kesempatan yang lebih besar dalam pengembangan pesantren.

Pimpinan pondok pesantren Ibnul Qoyyim putra tidak hanya memberikan apresiasi secara personal. Pimpinan memberikan apresiasi secara kolektif kepada asatidz pengabdian. Hal tersbut biasa dilakukan dengan melakukan acara syukuran antara pimpinan bersama asatidz pengabdian. Acara syukuran tersebut dilaksanakan sebagai ucapan terima kasih kepada asatidz secara keseluruhan karena telah bersedia untuk mengabdikan dirinya di pondok pesantren Ibnul Qoyyim Putra.

Sebagai bentuk apresiasi terhadap asatidz yang etos kerjanya baik, pimpinan pondok pesantren Ibnul Qoyyim putra juga memberi kesempatan untuk asatidz pengabdian melaksanakan ibadah haji. Hal ini bisa dilakukan mengingat pondok pesantren Ibnul Qoyyim putra merupakan amal usaha dari perkumpulan haji yaitu PDHI (Persatuan Djama'ah Haji Indonesia)

Ustadz Dhimas Rhomaulian, S.Pd.I selaku wakil direktur KMI Pondok Pesantren Ibnul Qoyyim Putra menuturkan bahwa pimpinan mempunyai sistematika tersendiri untuk memberikan reward kepada asatidz yang etos kerjanya baik. Pimpinan memberi kesempatan kepada asatidz pengabdian untuk melanjutkan pendidikan di perguruan tinggi. Setelah menyelesaikan strata satu nantinya asatidz akan dinaikkan statusnya dari pengabdian menjadi guru 
tetap. Dengan naiknya status tersebut maka asatidz pengabdian akan mendapat honor yang lebih baik dari pesantren. Lalu untuk asatidz pengabdian yang tidak berkuliah kebijakannya adalah memberi jangka waktu selama lima sampai enam tahun masa pengabdian agar bisa dinaikkan statusnya dari pengabdian menjadi guru tetap.

Kelima, melakukan evaluasi terhadap Asatidz yang etos kerjanya kurang baik. Fungsi pengendalian yang dilakukan oleh pimpinan adalah mengatur aktivitas anggotanya secara terarah dan dalam koordinasi yang efektif sehingga memungkinkan tercapainya tujuan bersama secara maksimal. Fungsi pengendalian dapat diwujudkan melalui kegiatan bimbingan, pengarahan, koordinasi dan pengawasan. Ketika ada seorang pengabdian yang etos kerjanya kurang baik hal tersebut akan menganggu perkembangan pondok pesantren Ibnul Qoyyim Putra. Ketika ada ustad pengabdian yang etos kerjanya kurang baik, pimpinan pondok pesantren Ibnul Qoyyim putra tidak langsung turun untuk melakukan tindakan. Pimpinan melakukan komunikasi. terlebih dahulu kepada koordiantor pengabdian atau biasa disebut koordianator pengasuhan agar memberi nasehat dan motivasi kepada ustad pengabdian yang etos kerjanya kurang baik. Dengan motivasi dan nasehat yang diberikan diharapkan ustad pengabdian yang bersangkutan bisa meningkatkan etos kerjanya agar bisa ikut adnil dalam memajukan pesantren.

Namun jika nasehat dan motivasi yang diberikan tidak mengubah etos kerja menjadi lebih baik pimpinan akan melakukan evaluasi dan terhadap pengabdian tersebut. Jika ustad pengabdian tersebut menerima evaluasi dari pimpinan dan mempunyai tujuan baik untuk memperbaiki etos kerjanya, maka pimpinan akan memberi kesempatan untuk kembali menjalankan tugastugasnya di pesantren. Namun jika ustad pengabdian tersebut tidak mempunyai maksud yang baik untuk memperbaiki etos kerjanya maka pimpinan akan memberhentikannya dari tugas pengabdian atau bahasa yang lebih sopan adalah diberikan surat ucapan terima kasih dan dipersilahkan untuk mengabdi di luar pondok pesantren Ibnul Qoyyim Putra.

Keenam, memotivasi Asatidz pengabdian untuk bekerja lebih baik. Telah dijelaskan pada subbab sebelumnya bahwa salah satu faktor yang mempengaruhi etos kerja asatidz pengabdian adalah motivasi dan nassehat dari pimpinan. Pimpinan pondok pesantren Ibnul Qoyyim putra berusaha sebaik mungkin untuk memberikan nasehat dan motivasi kepada asatidz pengabdian agar etos kerjanya meningkat. Pimpinan biasa memberi motivasi dan nasehat ketika diadakan rapat evaluasi antara pimpinan dan asatidz pengabdian yang diadakan setiap hari Jum'at setelah shalat Isya. Penyampaian nasehat dan motivasi juga dilakukan oleh pimpinan ketika rapat rutin bulanan dan agenda rapat tahunan dalam rangka menuyusun program kerja.

Ustad Dhimas Rhomaulian menuturkan bahwa pimpinan mengadakan agenda khusus dalam rangka memotivasi asatidz pengabdian untuk meningkat etos kerjanya. Agenda tersebut dinamai halaqoh malam Jum'at. Pada agenda itu pimpinan akan menyampaikan materimateri berkaitan dengan keislaman dan juga motivasi agar para asatidz bisa lebih ikhlas dan istiqomah dalm melaksanakan pengabdian di Pondok pesantren Ibnul Qoyyim Putra. selain di isi dengan kajiankajian keislaman, halaqoh malam Jum'at ini juga mengagendakan setoran tahfidzul Qur'an para asatidz kepada pimpinan. Setiap akan memulai sebuah pertemuan pimpinan juga selalu memberikan nasehat dan motivasi berkaitan dengan peningkatan etos kerja tersebut.

Ketujuh, menciptakan suasana kekeluargaan antara pimpinan dan 
Asatidz pengabdian. Pimpinan pondok pesantren Ibnul Qoyyim putra berusaha menjalin hubungan yang lebih dekat dengan asatidz pengabdian. Walaupun ada aturan-aturan mengikat yang harus dipatuhi asatidz pengabdian tetapi pimpinan memprioritaskan suasana kekeluargaan. Hal ini dimaksudkan agar antara pimpinan dengan asatidz pengabdian ataupun sesama asatidz pengabdian bisa saling mengerti kesibukan masing- masing dan bisa saling membantu menyelesaikan tugas-tugas pesantren.Ikatan kekeluargaan menurut ustad Dhimas Rhomauliaan selaku wakil direktur KMI adalah adanya uswah yang baik daripimpinan serta sifat Ta'awun antar sesame. Hasil dari suasana kekeluargaan yang dibangun oleh pimpinan pesantren adalah kedekatan dan komunikasi yang baik antara pimpinan Dengan asatidz pengabdian.

Komunikasi yang dijalin pimpinan dengan para asatidz pengabdian sudah baik sehingga para asatidz merasa nyaman berada di pesantren dan bisa melaksanakan tugas-tugas dari pesantren dengan baik.

Menurut ustadz Burhanadi Nurdin, pimpinan sangat terbuka dalam menjalin komunikasi dengan asatidz pengabdian sehingga para pengabdian bisa berdiskusi tanpa ada rasa canggung dengan pimpinan. Suasana kekeluargaan ini bisa memberikan timbal balik antara asatidz dan pimpinan. Asatidz bisa bekonsultasi tanpa canggung dengan pimpinan dan bisa memperoleh solusi dari pimpinan terkait problematika yang dialami dan pimpinan bisa mendapatkan etos dan kualitas kerja yang maksimal dari asatidz pengabdian. dengan adanya komunikasi yang baik antara pimpinan dan asatidz pengabdian koordinasi terkait tugas-tugas pesantren bisa dilakukan dengan lancar. Beberapa asatidz pengabdian bisa berkonsultasi langsung dengan pimpinan terkait problematika yang dialami baik itu terkait

tugas-tugas pesantren maupun
permasalahan individu.
permasalahan individu.

\section{Kesimpulan}

Etos kerja asatidz pengabdian di pondok pesantren Ibnul Qoyyim Putra cukup baik. Indikator dari etos kerja yang cukup baik dapat dilihat loyalitas atau kesetiaan para asatidz untuk melaksanakan pengabdian. Ciri lain dari etos kerja asatidz pengabdian pondok pesantren Ibnul Qoyyim putra adalah santun, rendah hati, sabar, dan memiliki emosi yang stabil dalam melaksanakan tugas- tugasnya.

Faktor yang mempengaruhi etos kerja asatidz pengabdian yaitu motivasi baik intrinsik maupun ekstrinsik. kesejahteraan yang dalam hal ini adalah honor yang diberikan pihak pesantren, motivasi dari pimpinan pesantren, etos kerja rekan pengabdian yang lain, dan pengaruh keilmuan Islam yang berkaitan dengan etos kerja. Peran pimpinan dalam meningkatkan etos kerja asatidz sudah cukup baik yaitu memberikan apresiasi kepada asatidz pengabdian yang kinerjanya baik, melakukan evaluasi terhadap asatidz yang kinerjanya kurang baik, menjaadi motivator untuk asatidz pengabdian dan menciptakan suasana kekeluargaan antara pimpinan dengan asatidz pengabdian.

\section{Daftar Pustaka}

Akkaya, Arzu. "Theories of educational management and leadership." Educational Review 73, no. 6 (2021).

Andjarwati, Tri. "Motivasi dari Sudut Pandang Teori Hirarki Kebutuhan Maslow, Teori Dua Faktor Herzberg, Teori X Y Mc Gregor, dan Teori Motivasi Prestasi Mc Clelland." jmm17 2, no. 01 (2015). 
Anoraga, Panji, dan Djoko Sudantoko. "Koperasi, Kewirausahaan dan Usaha Kecil.” Rineka Cipta, 2002.

Asifudin, Ahmad Janan. "Manajemen Pendidikan untuk Pondok Pesantren." Manageria: Jurnal Manajemen Pendidikan Islam 1, no. November (2016).

Asy'arie, Musa. "Islam Etos Kerja dan Pemberdayaan Ekonomi Umat." In Islam Etos Kerja dan Pemberdayaan Ekonomi Umat, 1997.

Budi, Iman Setya. "Pengaruh Religiusitas terhadap Etos Kerja Pedagang Banjar di Pasar Sudimampir Banjarmasin." Jurnal Ekonomi Syariah dan Hukum Ekonomi Syariah 5, no. 2 (2019).

Farisi, Salman Al. "MODEL INTEGRASI STUDI ISLAM: SAINS DAN BUDAYA NUSANTARA DI PESANTREN KHOLAF." Jurnal Penelitian Agama 19, no. 1 (2018).

Fitriyani, Diyah, Ocky Sundari, dan Johnson Dongoran. "FAKTORFAKTOR YANG MEMPENGARUHI ETOS KERJA PEGAWAI KECAMATAN SIDOREJO SALATIGA." Jurnal Ilmu Sosial dan Humaniora 8, no. 1 (2019).

Haryanto, Wahyu Dwi. "PENGARUH STRESS KERJA DAN MOTIVASI TERHADAP KEPUASAN KERJA ( Studi pada Perawat RSUD Kota Semarang )." Pengaruh Stres Kerja Dan Motivasi Terhadap Kepuasan Kerja (Studi Pada perawat RSUD Kota Semarang), no. 1 (2014).

Hidayat, Ara. "Pengelolaan Pendidikan (Konsep, Prinsip, dan Aplikasi dalam Mengelola sekolah dan Madrasah)." Universitas Pendidikan Indonesia (2012).

Irham, Muhammad. "Work Ethics in Islamic Perspective." Jurnal Substantia 14, no. 1 (2012).
Jannah, Raihanatul. "ETOS KERJA DAN POLA PENDIDIKAN PADA KELUARGA PENDULANG INTAN TRADISIONAL (STUDI KASUS DI KECAMATAN CEMPAKA KOTAMADYA BANJARBARU)." Jurnal Ta'lim Muta'allim 1, no. 1 (2015).

Mattayang, Besse. "TIPE DAN GAYA KEPEMIMPINAN: SUATU TINJAUAN TEORITIS." JEMMA | Journal of Economic, Management and Accounting 2, no. 2 (2019).

Maulindar, Joni, dan Annas Setiawan Prabowo. "Aspek Kepemimpinan Dalam Penyelarasan Strategi Bisnis TI/ SI." Jurnal Duta.Com 4 (2019).

Mulyasa, E. "Manajemen Berbasis Madrasah: Konsep, Strategi, dan Implementasi." Bandung: PT Remaja Rosdakarya (2007).

Nihwan, Muhammad, dan Paisun. "Tipologi Pesantren (Mengkaji Sistem Salaf dan Modern)." Jpik 2, no. 1 (2019).

PURWANTO, AGUS, Riza Primahendra, Ardian Sopa, Sekundina Williana Kusumaningsih, dan Rudy Pramono. "Pengaruh Gaya Kepemimpinan Tansformational, Authentic, Authoritarian, Transactional Terhadap Kinerja Guru Madrasah Aliyah di Tangerang." journal EVALUASI 4, no. 1 (2020).

Rahman, Habibur, dan Raima Selviana. "KEPEMIMPINAN DAN PENDIDIKAN ISLAM." Competence: Journal of Management Studies 12, no. 2 (2019).

Ratih, Andita, Ahmad Saalik Hudan Alfariz, Lina Putri Pasaribu, dan Hery Wibowo. "Transendensi Diri Pekerja Sosial (Studi kasus tentang transendensi diri pekerja sosial di Unit Pelaksana Tugas Pusat Kesejahteraan Sosial Dinas Sosial 
Kota Bandung)." Share: Social Work Journal 10, no. 1 (2020).

Sanjani, Maulana Akbar. "KEPEMIMPINAN

DEMOKRATIS KEPALA

SEKOLAH." Jurnal Serunai Administrasi Pendidikan 7, no. 1 (2019).

Sinamo, Jansen. "Delapan Etos Kerja Profesional: Navigator Anda Menuju Sukses." Bogor: Grafika Mardi Yuana. 20, no. 5 (2005).

Suri, Harsh. "Purposeful sampling in qualitative research synthesis." Qualitative Research Journal 11, no. 2 (2011).

Syarifah, Hidayatus. "PENDIDIKAN DALAM KELUARGA." Raudhah Proud To Be Professionals : Jurnal Tarbiyah Islamiyah 2, no. 1 (2017).

Tarmizi Gadeng. "Etos Kerja Dalam Perspektif Islam (Peluang Dan Tantangan Profesionalisme Masyarakat Muslim Dalam Era Modern)." Jurnal Mentari: Majalah Ilmiah Universitas Muhammadiyah Aceh 12, no. 1 (2009).

Toto Tasmara. "Etos kerja Pribadi Muslim." Angewandte Chemie International Edition, 6(11), 951952. (2013).

Winarsih, Sri. "Gaya Kepemimpinan Kepala Sekolah dalam Meningkatkan Kinerja Guru." International Conference of Moslem Society 2 (2018).

Yahya, Naufal. "Definisi Kepemimpinan Dalam Organisasi." Kabar Pasar Jurnal ilmu Ekonomi 1, no. 1 (2019). 